\section{Une ouverture sur le monde}

Nos lecteurs les plus perspicaces ont peut-être remarqué le changement que nous avons fait l'an passé dans l'énoncé de mission de la Revue. Nous y indiquons clairement maintenant que nous voulons accroître la pertinence de la Revue pour la santé mondiale. En effet, il est difficile d'imaginer que la population canadienne puisse jouir d'un niveau de santé élevé si le reste du monde ne peut aspirer à la santé. De plus, la santé mondiale est un domaine en pleine croissance dans les nouvelles Écoles de santé publique qui ont été créées récemment d'un bout à l'autre du pays, ce qui permettra de développer encore l'expertise canadienne dans ce domaine. Cette expertise est d'autant nécessaire parce que la vision de la santé mondiale comme visant l'équité en santé à l'échelle mondiale, dans un contexte de mondialisation complexe et profondément inégale, pose des défis épistémologiques, méthodologiques et éthiques, nécessitant des approches pluri- et transdisciplinaires et transsectorielles. Il faut donc une pratique et une recherche fondées sur la créativité, la rigueur et des collaborations réelles.

Les experts canadiens dans le domaine des maladies transmissibles, de l'organisation des soins et de la santé maternelle et infantile ont toujours joui d'une réputation enviable auprès des organismes internationaux et des pays dans lesquels ils oeuvraient. Cependant, depuis une quinzaine d'années le Canada devient un acteur majeur dans le domaine de la recherche en santé mondiale. Est-il besoin de rappeler que lors de la création des Instituts de recherche en santé du Canada, la santé mondiale fut l'un des premiers thèmes prioritaires à être développés? Sous le leadership notamment d'une collaboration étroite entre l'Institut de la santé publique et des populations et le secteur santé du Centre de recherches pour le développement international, les investissements canadiens dans ce domaine se sont accrus considérablement. Ces collaborations ont donné lieu à de nombreux programmes de financement de projets, de soutien à des infrastructures performantes et à des programmes de formation en recherche - à la fois dans des approches spécifiquement identifiées comme "santé mondiale » et de plus en plus comme une composante normale et normalisée de la recherche en santé. Depuis déjà quelques années, la Revue offre aux chercheurs canadiens et aux projets qu'ils pilotent des possibilités réelles de publier les résultats de leurs travaux. À long terme cependant, nous voulons devenir un véhicule pour publier les travaux de qualité, qui se situent aux confins des domaines de recherche que sont la santé mondiale et la santé publique ${ }^{1}$.

C'est dans cet esprit qu'à la demande de l'une de ses fondatrices, $\mathrm{D}^{\text {re }}$ Noni MacDonald, nous nous associons à l'organisme MicroResearch ${ }^{2}$ pour publier sous forme de lettre à l'Éditeur des rapports de recherche pilotés par cette organisation. En effet, MicroResearch s'est donné comme mission d'accroître la capacité de recherche en santé en Afrique sub-saharienne. Par des ateliers de formation, des petites subventions de démarrage et un mentorat des acteurs locaux, l'organisme soutient le développement d'études multidisciplinaires qui impliquent les communautés locales et qui visent l'amélioration de la santé. Cet accompagnement se poursuit jusqu'à la publication des résultats, dans le cas qui nous occupe, sous la forme de lettres à l'Éditeur. Ces lettres ont été soumises à l'examen par les pairs à travers MicroResearch et fournissent des résultats issus de recherches

\section{A window on the world}

Observant readers will have perhaps noticed the change we made last year to the Journal's mission statement. We now clearly state that we wish to increase the relevance of the Journal to global health. Indeed, it is hard to imagine Canada's population enjoying a high standard of health while so many other parts of the world cannot look forward to even a basic level. In addition, global health is a burgeoning field in the schools of public health that have recently been created from one end of the country to the other, which will allow for further development of Canadian expertise in this field. This expertise is all the more important because global health's vision of promoting health equity on a global scale, in a context of complex and profoundly unequal globalization, poses epistemological, methodological and ethical challenges that necessitate approaches that are multi- and transdisciplinary as well as trans-sectoral. What is needed therefore is practice and research based on creativity, rigour and true collaborations.

Canadian experts in the fields of infectious disease, health care and maternal and child health have always enjoyed an enviable reputation among international bodies and in the countries in which they work. However, over the past 15 years or so, Canada has become a major player in the field of global health research. We should remember that upon the creation of the Canadian Institutes of Health Research, global health was one of the first key issues to be developed.

Under the leadership of a close collaboration between the Institute of Population and Public Health and the health sector of the International Development Research Centre, Canadian investments in this field have grown significantly. These collaborations have resulted in numerous project funding programs, support for efficient infrastructure, and research training - both for approaches specifically identified as "global health" and increasingly as a regular and standardized component of health research. For several years already, the Journal has offered Canadian researchers, and the projects they run, real possibilities of publishing the results of their work. In the long term, however, we want to become a vehicle for the publication of quality works that fall within the confines of the research fields of global health and public health. ${ }^{1}$

It is in this spirit that, at the request of one of its founders, Dr. Noni MacDonald, we partner with MicroResearch ${ }^{2}$ to publish, as letters to the Editor, research reports piloted by this organization. In fact, MicroResearch has given itself the mission of growing health research capacity in sub-Saharan Africa. Through training workshops, small start-up grants and the mentoring of local players, the organization supports the development of multidisciplinary studies that involve local communities and target health improvement.

This support continues through the publication of results; in this case, in the form of letters to the Editor. These letters have been subjected to peer review through MicroResearch and present the results from original research. We are very proud to publish, in this issue, two letters that have been submitted to us.

This represents the first step in our mission to make the Canadian Journal of Public Health (CJPH) a vehicle for the publication of 
originales. Nous sommes très fiers de publier dans ce numéro deux lettres qui nous ont été soumises.

Ceci représente la première étape dans notre projet de faire de la Revue canadienne de santé publique (RCSP) un véhicule pour publier la recherche de qualité dans le domaine de la santé mondiale, que celle-ci soit conduite par des chercheurs canadiens ou non.

Une deuxième étape sera une rubrique spéciale d'une douzaine d'articles de recherche originaux, de commentaires critiques et de brefs comptes rendus découlant de la Conférence canadienne sur la santé mondiale de novembre 2015, qui avait pour thème le « Renforcement des capacités pour la santé mondiale : recherche et pratique ».L'engagement et l'apprentissage mutuels entre la recherche et la pratique, et entre les érudits et les praticiens du Nord et du Sud de la planète, caractérisent le travail canadien en santé mondiale et font fortement écho aux valeurs et à la vision de la Revue. Cette rubrique spéciale est le fruit d'une collaboration entre la Revue et la Société canadienne de santé internationale, hôte de la conférence annuelle et hôte conjoint de la prochaine édition biennale du Symposium mondial sur la recherche en systèmes de santé, " Des systèmes de santé résilients et adaptés aux besoins d'un monde en évolution ", qui aura lieu à Vancouver (Colombie-Britannique) en novembre 2016. Nous voulons engager une réflexion transdisciplinaire et transsectorielle avant ce symposium, en espérant que notre rubrique spéciale favorisera la réflexion et les échanges entre des thèmes et des domaines trop souvent isolés les uns des autres et du " courant dominant » de la santé publique. Nous avons également invité les auteurs dont les manuscrits proposés ne cadraient pas entièrement avec le thème de notre rubrique spéciale à les soumettre à la Revue par les voies habituelles; nous espérons que beaucoup d'entre eux - ainsi que d'autres - décideront de le faire. Nous voulons explorer un éventail de modalités et de sujets liés à la santé mondiale - dont certains, espérons-le, paraîtront un jour régulièrement dans la Revue.

Avec notre nouvelle option de publication de résumés détaillés sous forme de lettres à l'Éditeur afin de rendre compte brièvement de résultats de recherche, et avec notre rubrique spéciale (dont le fait d'inviter les auteurs en santé mondiale à explorer la nouvelle formule des «Innovations dans les politiques et la pratique » récemment ajoutée à la Revue), nous amorçons un plan à plus long terme : souligner et institutionnaliser en même temps la santé mondiale comme faisant partie intégrante de la recherche, de l'érudition et de la pratique en santé publique. Nous voulons faire de la Revue canadienne de santé publique un lieu privilégié pour publier, lire et débattre des travaux engagés de recherche et d'érudition en santé mondiale - tant pour les Canadiens que pour les étrangers. Les Canadiens ont beaucoup à apprendre du reste du monde, et beaucoup à offrir.

Louise Potvin, Ph.D.

Rédactrice en chef, Université de Montréal

Christina Zarowsky

Rédactrice

doi: 10.17269/CJPH.106.5500

\section{RÉFÉRENCES BIBLIOGRAPHIQUES}

1. Koplan JP, Bond TC, Merson MH, Reddy KS, Rodriguez MH, Sewankambo NK, et al. Towards a common definition of global health. Lancet 2009;373:1993-95. doi: 10.1016/S0140-6736(09)60332-9.

2. Sur Internet : http://www.microresearch.ca/goals-and-objectives/ quality research in the field of global health, whether conducted by Canadian researchers or not.

A second step is a forthcoming special section of approximately a dozen original research papers, critical commentaries and brief reports arising from the November 2015 Canadian Conference on Global Health, the theme of which was "Capacity Building for Global Health: Research \& Practice.” Mutual engagement and learning between research and practice, and between scholars and practitioners in and from the global North and the global South, characterizes Canadian work in global health and resonates strongly with the values and vision of CJPH. This special section is a collaboration between CJPH and the Canadian Society for International Health, host of the annual conference and co-host of the next biennial Global Symposium on Health Systems Research, "Resilient and Responsive Health Systems for a Changing World," to be held in Vancouver, BC in November 2016. We want to engage cross-disciplinary and cross-sectoral thinking in advance of the Symposium and hope that the special section will foster reflection and exchange across themes and fields which are too frequently isolated from each other and from "mainstream" public health. We have also invited authors whose proposed manuscripts do not align closely with the theme of the special section to submit through regular channels to the Journal, and we hope that many of them - and others - decide to do so. We aim to explore a range of modalities and topics in global health - some of which, we hope, will come to feature regularly in the Journal.

Through the new option of extended abstracts as letters to the editor to report briefly on research findings, and through this special section (including inviting global health authors to explore the new format of "Innovations in Policy and Practice" recently introduced in CJPH), we launch a longer-term plan to simultaneously highlight and mainstream global health as an integral dimension of public health research, scholarship and practice. Our intent is that the Canadian Journal of Public Health become a prime site to publish, read and debate engaged research and scholarship in global health - both for Canadians and internationally. Canadians have much to learn from the world, and much to offer.

\section{Louise Potvin, PhD \\ Editor in Chief, Université de Montréal}

\section{Christina Zarowsky \\ Senior Editor}

doi: $10.17269 / \mathrm{CJPH} .106 .5500$

\section{REFERENCES}

1. Koplan JP, Bond TC, Merson MH, Reddy KS, Rodriguez MH, Sewankambo NK, et al. Towards a common definition of global health. Lancet 2009;373:1993-95. doi: 10.1016/S0140-6736(09)60332-9.

2. Available at: http://www.microresearch.ca/goals-and-objectives/ 